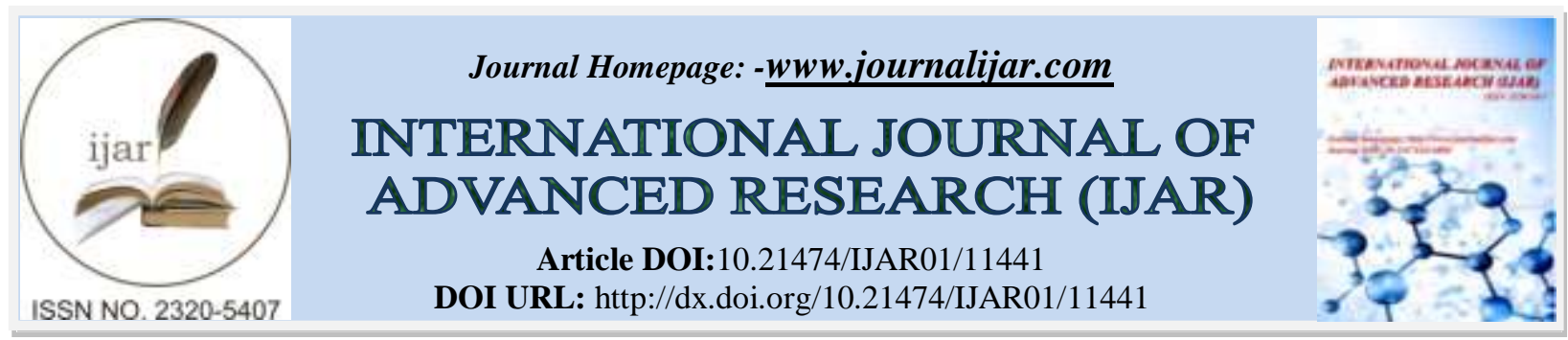

RESEARCH ARTICLE

\title{
HETEROSIS STUDIES OF SUGAR CONTENT INHERITANCE IN SEGREGATING POPULATION OF COWPEA (Vigna unguiculata L. Walp)
}

Mohammed Mallam ${ }^{1}$, Mohammed Maigari Mangadu ${ }^{1}$, Rukaiya Sami Sami ${ }^{2}$ and Hauwau Muhammad ${ }^{3}$

1. Federal College of Education (Tech), Gombe State - Nigeria.

2. Ahmadu Bello University Zaria Department of Plant Sciences.

3. University of Maiduguri Department of Biological Sciences.

\section{Manuscript Info}

Manuscript History

Received: 31 May 2020

Final Accepted: 30 June 2020

Published: July 2020

Key words:-

Heterosis, Seed Sugar content, Cowpea

\begin{abstract}
The research was conducted from 2013 to 2016 at the Ahmadu Bello University AGRA Screen house and IAR Research field, Samaru Zaria located on latitude $11^{\circ} 11^{\prime}$, longitude $07^{\circ} 38^{\prime}$ and $686 \mathrm{~m}$ above the sea level. This region belongs to the Northern Guinea savannah ecological zone of Nigeria, with a view of identifying promising segregants and to evaluate the potential for genetic improvement of nutritional quality of cowpea for sweetness which is an important component of taste in cowpea for cowpea consumers especially the diabetic patient which is in the increase globally, Cowpea seeds sugar content was measured using Anthrone method which is the best colorimetric Quantitative analysis of monosaccharide, disaccharide and glycoside present in a given sample. The analysis of variance (ANOVA) indicated a significant variation exist with regards to this trait in all the selected genotypes based on selection intensity of $10 \%$ ( $n$ for $P_{1}, P_{2}, F_{1}=20$. The highly significant difference in mean squares implied that there is discernable evidence of inherent genetic variability among the cowpea genotypes with respect to this trait. The means generation were separated, all the vertical means with the same letter do not differ significantly at $(\mathrm{P}=0.05)$ using LSD. The mid parent Heterosis is $61 \%$ and the best parent Heterosis is $37 \%$ of sugar contents which is high.
\end{abstract}

Copy Right, IJAR, 2020,. All rights reserved.

\section{Introduction:-}

Cowpea plays a substantial role by serving as a grain and vegetable crop mainly for the rural people in the East, West, South and Central parts of Africa (Mortimore et al., 1997). Green seeds, young fresh leaves and immature green pods are eaten as a vegetable (Gerrano et al. 2015, 2017, 2019). According to Diouf (2011), cowpea feeds millions of people in the developing world with an annual worldwide production estimated around 4.5 million metric tons on 12 to 14 million ha. The high protein content represents a major advantage in the use of cowpea in nutritional products for infant and children's food, and to compensate for the large proportion of carbohydrates often ingested in African diets (Lambot, 2002). Cowpea grain with a sweet taste is rare, but seems to be preferred by many consumers in West Africa. Price and quality studies in Senegalese markets indicate that for a $1 \%$ increase in sucrose content consumers are willing to pay 13 to 59 FCFA/kg more. In Niger, preliminary price and quality data indicate that consumers pay a premium for sweeter grain. Formal blind taste tests conducted at Purdue University showed that the Cameroon sweet line was preferred to its non-sweet >sister= (closely- related) line. Informal taste tests in 
California also indicated that the flavor of the Cameroon sweet cowpea was preferred to California blackeyes by most tasters. Thus, there is a tremendous opportunity to enhance cowpea consumption in both Africa and the United State of America by developing better tasting cowpea varieties.

Sangwan and Lodhi (1995) studied Heterosis for yield and yield components such as seed size and sucrose content in 25 crosses involving 11 cowpea varieties. Better parent Heterosis ranged from $28.8 \%$ to $84.0 \%$ for seed yield/ha. Heterosis up to $81.6 \%$ over better parent was observed for pod/plant, $35.6 \%$ for pod length, $20.4 \%$ for seed/pod, and $36 \%$ for seed weight/plant. Hybrid Fos- $1 \times$ Co1, Fos- $2 \times$ EC 4216, and EC $4216 \times$ C28 were most promising Bhor et al. (1997) studied $\mathrm{P}_{1}, \mathrm{~F}_{1}$, and $\mathrm{F}_{2}$ populations of 14 crosses and observed $63.8 \%$ better parent Heterosis for seed yield in the cross V240 $\times$ VCM8. They further observed that the Heterosis was $4.3 \%$ for plant height and $91.52 \%$ for days to maturity. They observed that progeny derived from crosses showing high Heterosis also showed high inbreeding depression indicating the importance of non additive gene action. Bhushana et al. (2000) estimated Heterosis for several traits in 36 hybrids. They observed a mid parental Heterosis of $171.5 \%$ for number of secondary branches/plant, $11.5 \%$ for pods/plant, $105.3 \%$ for seed yield/plant, $75.5 \%$ for primary branches/plant, $30.31 \%$ for pod length, and $20 \%$ for 100 seed weight. They also observed $-15.9 \%$ Heterosis for days to $50 \%$ flowering. Heterosis for fodder yield was reported by Ponmariammal and Das (1996) and High values for Heterosis indicates good genetic diversity among cowpea varieties used in these studies indicating the possibility of isolating high yielding transgressive segregates from hybrid populations. However, the estimates for Heterosis in most cases is from space planted $F_{1}$ hybrids, which may not be a true index of performance under normal plant populations used for commercial crops. Therefore, there is a need to estimate Heterosis under recommended plant population for maximum yield of cowpea. Several earlier workers have also reported high heritability coupled with high genetic advance of these traits under study (Nwosu et al. 2013 and Tudu et al. 2015)

\section{Heterosis:}

Several studies show that cowpea hybrids can exhibit considerable Heterosis for many traits such as grain size, protein and sucrose content. Data on preferences for biochemical characteristics such as sucrose content, protein content, and cooking time comes mainly from studies conducted in Senegal and Niger. Singh A. et al (2004), these studies suggest that consumers are willing to pay for sweeter-tasting cowpeas, higher protein, and shorter cooking time. The discovery of the sweet trait opens up the possibility of developing new products and markets for cowpea in the United State and elsewhere. In spite of the great importance of this crop to the people where it is grown, its productivity is very low due to many biotic and abiotic stress factors. These factors include attack of insect pests and disease pathogens, as well as drought and heat. Although, considerable Progress has been made, through conventional genetics and breeding, on cowpea improvement over the decades with respect to resistance to most of these stress factors (Singh, 2007), however, the area of improving the nutritional quality for sweetness and other farmer preferred qualities is a vital area of future breeding programmed to focus attention on which is the essence of this research.

The discovery of sweet trait opens up the possibility of developing new products that are very attractive to consumers and thus larger markets for cowpea (Ehlers et al., 2000; Hall et al., 2003). In view of the above benefit and the monogenic nature of trait associated with cowpea sugar content which can be easily transfer through simple planned breeding program involving segregating generations this research is justified.

\section{Materials And Methods:-}

Experimental site:

The research was conducted from 2013 to 2016 at the Ahmadu Bello University AGRA Screen house and IAR Research field, Samaru Zaria located on latitude $11^{\circ} 11^{\prime}$, longitude $07^{\circ} 38^{\prime}$ and $686 \mathrm{~m}$ above the sea level. This region belongs to the Northern Guinea savannah ecological zone of Nigeria. (Google Earth).

\section{Experimental materials:}

The materials for the study were IAR Cowpea Accessions from Cowpea research programmed collections of Ahmadu Bello University, Samaru Zaria. Thirty - Two (32) Accessions of the experimental materials were screen for sugar content, Two parent (2) Janwake and Sababba, genetically diverse Accessions were selected based on their sugar content, to develop the populations for the Heterosis studies of cowpea sugar content inheritance in the segregating Generation. 


\section{Estimation of genetic parameters:}

Genotypic and phenotypic variances, coefficient of variation, and Genetic advancement were computed based on mean and variances calculated using data of each treatment. After the Laboratory Sugar Analysis, were analyzed by ANOVA (Analysis of variance) and Descriptive Statistics in Analysis toolpak of Microsoft excel computer program.

\section{Generation of Populations:}

The patterns of inheritance of the characters or traits, including genetic effects, from populations developed from two parents in two (2) hybrid combinations obtained from crosses of these two (2) genetically diverse parents which were selected based on their sugar content, were studied. All crosses were made on plants growing in pots in the Screen house 2013 and 2014, and also during the field Evaluation in the 2015/2016 rainy season, with emasculation of the flower buds and subsequent hybridization that produced the three generations of $\mathrm{P}_{1}, \mathrm{P}_{2}$ and $\mathrm{F}_{1}$, Populations.

\section{Experimental design:}

In all the stages, four seeds were sown in plastic pots of $5 \mathrm{~L}$ capacity and thin to two. The pots were filled with a mixture of loamy soil and in each pot, $2 \mathrm{~g}$ of compound fertilizer (NPK 15:15:15), thoroughly mixed with the soil that at least provide the $20 \%$ of nitrogen starter dose for proffer nodulation. Completely randomized Block design was used, for the optimum F1 seed productions, all the necessary data were recorded at field evaluation.

\section{Field Layout:}

The research field was ridged on $20^{\text {th }}$ July 2016., planted on $25^{\text {th }}$ July 2016. Field experimental, families were grown in a compact family block design with three replications in three separate but adjacent fields ten rows of ninety by forty- five centimeter row to row and plant to plant distance for parent one $\left(\mathrm{P}_{1}\right)$, parent two $\left(\mathrm{P}_{2}\right)$ and $\mathrm{F}_{1}$ with total plant population of 250 plants each. The fields were sprayed with Cypermethrin to control pest at 1 litre/ha equivalent $100 \mathrm{ml} / 20$ litre Knapsack at the onset of flowering to maturity. At maturity each entry of the three populations were harvested and selected genotypes were put in a well level poly ethane bags for analysis. All agronomic principles were fully adhered to, throughout the growing period.

\section{Data analysis:}

The three populations of Parent 1 , Parent 2 and $F_{1}$ data collected were subjected to analysis of variances (ANOVA) to test their significance differences and their mean were separated using LSD at (0.05) to evaluate the performance of the various genotypes that shows some degree of variation among the various genotypes selected for this study.

Heterosis $(\mathrm{H} \%)$ quantified as deviation of $\mathrm{F}_{1}$ value from the mid-parent (MP), also from the better parent values (heterobeltiosis, HB \%). As outlined by Fonseca and Paterson (1968):

$$
\begin{aligned}
& \mathrm{H} \%=\left[\left(\mathrm{F}_{1}-\mathrm{MP}\right) / \mathrm{Mp}\right] \times 100 \\
& \mathrm{HB} \%=\left[\left(\mathrm{F}_{1}-\mathrm{BP}\right) / \mathrm{BP}\right] \times 100 \\
& \text { Where, } \\
& \mathrm{MP}=\left(\mathrm{P}_{1}-\mathrm{P}_{2}\right) / 2 \text { and } \\
& \mathrm{BP}=\text { best parent. }
\end{aligned}
$$

\section{Results And Discussion:-}

\section{Mean sugar content results and analysis:}

Means of the three generation of $\mathrm{P}_{1}, \mathrm{P}_{2}$, and $\mathrm{F}_{1}$ to determine the Heterosis of cowpea sugar content which is one of the most important components of taste in cowpea are listed in (TABLE 1) of the crosses between Janwake and Sababba. The means generation were separated, all the vertical means with the same letter do not differ significantly at $(\mathrm{P}=0.05)$ using LSD. The phenotypic variance and phenotypic coefficient of variation were higher than corresponding genotypic variance and genotypic coefficient of variation (Table 2) for all of the traits under this study indicated the presence of less environmental effect upon the concerned traits. Which shows the selected genotypes in the present study exhibited considerable amount of variation for the trait of sugar content. The present finding is in accordance with the finding of Khan (2015), The minimum apparent differences in GCV and PCV coupled with low environmental influence for the trait studied implied that the trait is mostly governed by genetic factors with little role of environment in the phenotypic expression of this trait, (Table 2) Thus, selection of trait on the basis of the phenotypic value may be effective. Graphical presentation of Sugar content Heterosis of parental with F1 progenies, (Figure 1) presented below. 
Table 1:- Means Sugar Content In Millimole/Litre Of P1, P2, F1 Of Crosses Between Janwake And Sababba Data.

\begin{tabular}{|c|c|c|c|c|c|}
\hline$N O$ & $P 1$ & $N O$ & $P 2$ & $N O$ & F1 \\
\hline 1 & $20.7 \mathrm{ab}$ & 1 & $10.2 \mathrm{~g}$ & 1 & $17.6 \mathrm{fg}$ \\
\hline 2 & $14.2 \mathrm{e}$ & 2 & $11.0 \mathrm{~g}$ & 2 & $17.2 \mathrm{~g}$ \\
\hline 3 & $9.2 \mathrm{~h}$ & 3 & $7.1 \mathrm{~h}$ & 3 & $17.0 \mathrm{gh}$ \\
\hline 4 & $17.4 \mathrm{~d}$ & 4 & $5.6 \mathrm{i}$ & 4 & $19.2 \mathrm{e}$ \\
\hline 5 & $6.8 \mathrm{i}$ & 5 & $4.8 \mathrm{j}$ & 5 & $18.6 \mathrm{e}$ \\
\hline 6 & $9.0 \mathrm{~h}$ & 6 & $7.0 \mathrm{~h}$ & 6 & $18.3 \mathrm{ef}$ \\
\hline 7 & $17.0 \mathrm{~d}$ & 7 & $15.7 \mathrm{bc}$ & 7 & $22.0 \mathrm{c}$ \\
\hline 8 & $17.8 \mathrm{~d}$ & 8 & $14.6 \mathrm{~cd}$ & 8 & $23.0 \mathrm{~b}$ \\
\hline 9 & $11.6 \mathrm{fg}$ & 9 & $13.4 \mathrm{de}$ & 9 & $16.2 \mathrm{hi}$ \\
\hline 10 & $22.3 \mathrm{a}$ & 10 & $16.7 \mathrm{ab}$ & 10 & $20.7 \mathrm{~d}$ \\
\hline 11 & $11.5 \mathrm{fg}$ & 11 & $6.2 \mathrm{hi}$ & 11 & $19.5 \mathrm{de}$ \\
\hline 12 & $10.6 \mathrm{fgh}$ & 12 & $6.4 \mathrm{hi}$ & 12 & $24.8 \mathrm{a}$ \\
\hline 13 & $11.7 \mathrm{f}$ & 13 & $7.5 \mathrm{~h}$ & 13 & $18.7 \mathrm{e}$ \\
\hline 14 & $9.3 \mathrm{~h}$ & 14 & $11.4 \mathrm{fg}$ & 14 & $20.4 \mathrm{~d}$ \\
\hline 15 & $9.1 \mathrm{~h}$ & 15 & $17.3 \mathrm{a}$ & 15 & $15.5 \mathrm{i}$ \\
\hline 16 & $10.0 \mathrm{gh}$ & 16 & $5.2 \mathrm{i}$ & 16 & $19.4 \mathrm{e}$ \\
\hline 17 & $18.2 \mathrm{~cd}$ & 17 & $12.6 \mathrm{ef}$ & 17 & $20.8 \mathrm{~d}$ \\
\hline 18 & $16.4 \mathrm{e}$ & 18 & $5.1 \mathrm{i}$ & 18 & $15.3 \mathrm{j}$ \\
\hline 19 & $19.5 \mathrm{bc}$ & 19 & $13.0 \mathrm{e}$ & 19 & $20.5 \mathrm{~d}$ \\
\hline 20 & $18.3 \mathrm{~cd}$ & 20 & $5.3 \mathrm{i}$ & 20 & $19.1 \mathrm{e}$ \\
\hline
\end{tabular}

Anthrone Method For Sugar Content Analysis

Vertical Means with the same letters do not differ significantly, At $\mathrm{P}=0.05$, using LSD

Figure 1:- Mean Sugar Content in Millimole/Litre of P1, P2, F1 Of Crosses Between Janwake And Sababba Heterosis

\section{Graphical Presentation:}

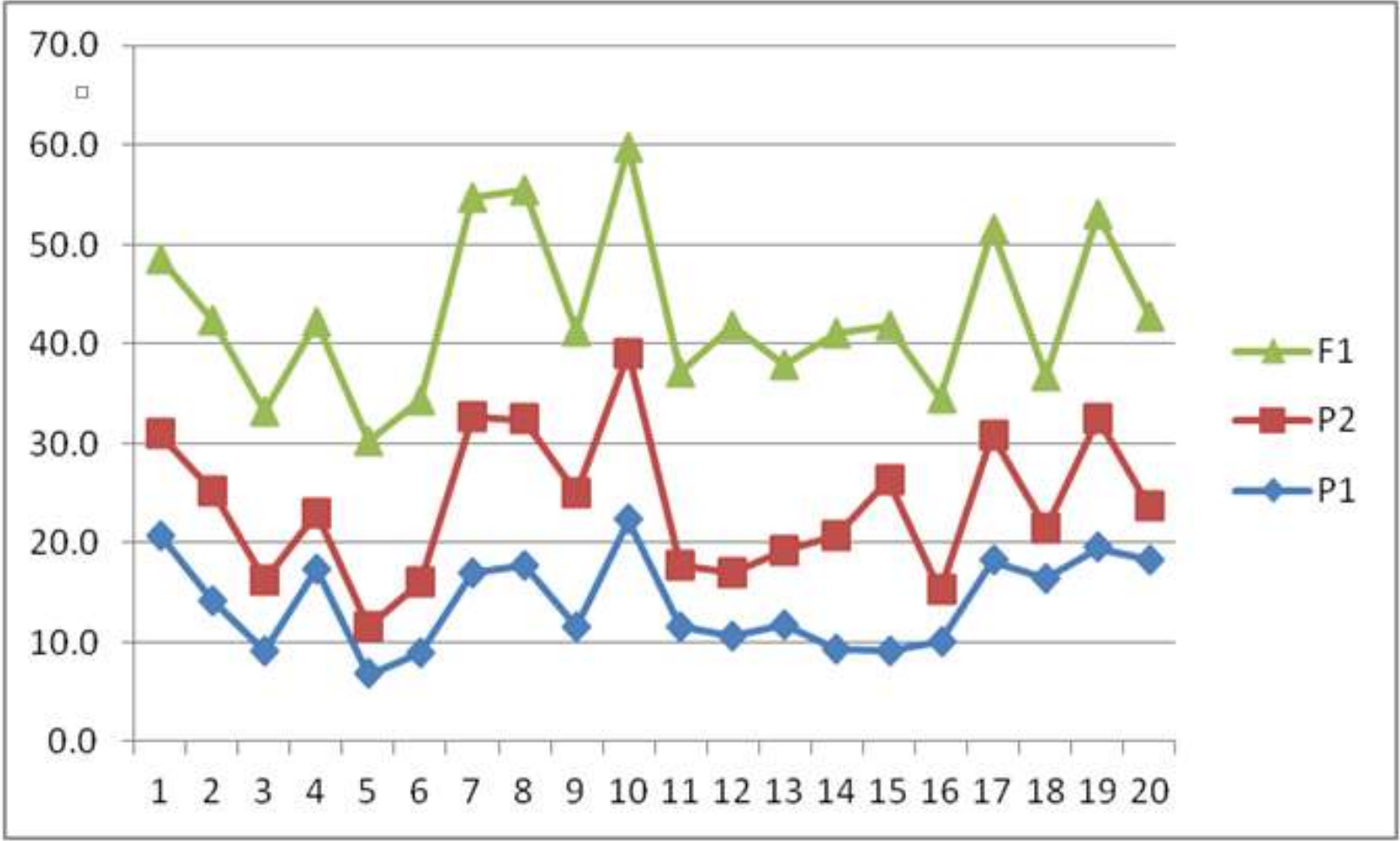




\section{Generations Genotyps:}

Table 2:- Heterosis Of Sugar Content Quantitative Traits Analysis Of Jan Wake And Sababba Hybrid. QUANTITATIVE TRAITS ANALYSIS OF JAN WAKE AND SABABBA HYBRID

\begin{tabular}{|c|c|}
\hline \multicolumn{2}{|l|}{ GENOTYPIC COEFFICIENT OF VARIATION (GCV \%) } \\
\hline PHENOTYPIC COEFICIENT OF VARIATION (PCV \%) & $56.32 \%$ \\
\hline ENVIRONMENTAL VARIANCE & $\mathbf{1 5 . 3 0}$ \\
\hline BROAD-SENSE HERITABILITY (h2b \%) & $\mathbf{9 8 . 8 3 \%}$ \\
\hline NARROW-SENSE HERITABILITY (hNS) & $28.00 \%$ \\
\hline MID-PARENT HETEROSIS (H\%) & $61.00 \%$ \\
\hline BEST-PARENT HETEROSIS (HETEROBELTIOSIS) & $37.00 \%$ \\
\hline
\end{tabular}

\section{Conclusion:-}

The extent to which variation could be transferred from parent to offspring would suggest how far the variation is heritable likewise the genetic advance which has direct bearing on responsive to selection. Genotypic selection of cowpea with high sugar content could be effective in the development of cowpea variety with high nutritional value that could be used in foods in this case; increasing the sugar content by genetic improvement is a low cost high, benefit strategy for improving the nutritional quality of cowpea variety. Selection for sugar content may be profitable and feasible in the later segregating populations the incorporation of sweet genes in combination to increase sweetness is practical in cowpea. The recurrent selection breeding method would be an effective means of transferring the genes for seed sugar content among cowpea genotypes. Jackson, (2005) noted that most sugarcane breeding programmed worldwide use recurrent selection for the increase in sugar content of new cultivars such breeding programmed will be applicable for improvement of sugar content in cowpea.

\section{Recommendations:-}

Sugar content, trait showed high broad sense heritability, moderate to high genotypic and phenotypic coefficient of variations with significant Hetorosis (Audilaksh et al, 2010) in Sorghum. Earlier studies on different crops revealed that sucrose content was a polygenic trait. (Ky, et al, 2000; Maughan, et al 2000; Audilakshmi, et al 2010) as such this shows considerable progress can be made through simple planned breeding program involving segregating generations.

\section{References:-}

1. Audilakshmi S., Mall A.K., Swarnalatha M., and Seetharama N., (2010). Inheritance of sugarconcentration in stalk (brix), sucrose, stalk and juice yield in sorghum. Biomass Bioenergy, 34(6): 813-820

2. Bhor, T.J., N.S. Kute, A.D. Dumbre, and N.D. Sarode. 1997. Heterosis and inbreeding depression in cowpea. Indian Journal of Agricultural Research 31: 122-126.

3. Bhushana, H.O., K.P. Viswanatha, P.A Runachala, and G.K. Halesh. 2000. Heterosis in cowpea for seed yield and its attributes. Crop Research (Hisar) 19: 277-280.

4. Diouf D (2011). Recent advances in cowpea [Vigna unguiculata (L.) Walp.] "omics" for genetic improvement. Afr. J. Biotechnol., 10(14): 2803-2819.

5. Ehlers, J.D., Hall, A.E., Patel, P.N., Roberts, P.A. and Matthews, W.C., (2000). Registration California blackeye 27 cowpea. Crop Sci., 40: 854-855.

6. Fonseca S. and Paterson F.L., (1968). Hybrid vigour in seven diallel cross in common wheat (Triticum aestivum L.) Crop Sci., 8: 85-88.

7. Gerrano A.S., Adebola P.O., van Rensburg W.S., Laurie S.M.. 2015. Genetic cowpea (Vigna unguiculata (L.) Walp.) genotypes. S Afr J Plant Soil. 32(3):165-174. doi: 10.1080/02571862.2015.1014435 [Google Scholar],

8. Gerrano A.S., Jansen van rensburg W.S., Adebola P.O. 2017. Nutritional composition of immature pods in selected cowpea (Vigna unguiculata(L.) Walp.) genotypes in South Africa. Aust J Crop Sci. 11:134-141. doi: 10.21475/ajcs.17.11.02.p72 [Google Scholar],

9. Gerrano A. S., Jansen van Rensburg W. S., Venter S. L., Shargie N. G., Amelework B. A., Shimelis H. A., Labuschagne M. T., 2019. Selection of cowpea genotypes based on grain mineral and total protein content. Acta Agric Scand B Soil \& Plant Sci. 62:155- 166doi_org/10.1080/09064710.2018.1520290. [Google Scholar])

10. Hall A.E., Cisse N., Thiaw S., Elawad HOA, Ehlers J.D., (2003). Development of cowpea

11. Cultivars and germplasm by the Bean/Cowpea CRSP. Field Crops Res 82:103-134 
12. Khan H, Viswanatha KP, Sowmya HC. Study of genetic variability parameters in cowpea [Vigna unguiculata (L.) Walp.] germplasm lines. An international quarterly journal of life sciences. 2015; 10(2):747-750.

13. Ky C.L., Doulbeau B., Guyot B., Akaffou S., Charrier A., Hamon S., Laouarn J. , Noiret M., (2000). Inheritance of coffee bean sucrose content in interspecific cross Coffea pseudozanguebariae X Coffea Liberia dewevrei. Plant Breeding, 119(2): 165-168.

14. Lambot C., (2002). Industrial potential of cowpea P. 367-375 In C.A. Fatokum et al (ed) Challenges and Opportunities for enhancing Sustainable Cowpea Production. Of The World Cowpea Conference III held at the International Institute of Tropical Agriculture (IITA), Ibadan, Nigeria 4-8 September, 2000 IITA Ibadan Nigeria.

15. Maughan P.J., Saghai M.A., Maroof, and Buss G.R. (2000). Identification of quantitative trait loci sucrose content in soybean (Glycine max). Molecular Breeding, 6: 105-111.

16. Mortimore MJ, Singh BB, Harris F, Blade SF (1997). Cowpea in Traditional Cropping Systems. In: Advances in Cowpea Research, Singh, B.B., D.R. Mohan Raj, K.E. Dashiell and L.E.N. Jackai (Eds.). IITA and JIRCAS, Hong Kong, pp 99-113.

17. Nwosu DJ, Olatunbosun BD, Adetiloye IS. 2013. Genetic variability, heritability and genetic advance in cowpea genotypes in two agro-ecological environments. Greener Journal of Biological Sciences 3: $202-207$.

18. Ponmariammal, T. and L.D. Vijendra Das. 1996. Heterosis for fodder yield in cowpea. Madras Agricultural Journal 83: 658-659.

19. Sangwan, R.S. and G.P. Lodhi. 1995. Heterosis for grain characters in cowpea (Vigna unguiculata [L.] Walp.). Legume Research 18: 75-80.

20. Singh A., Hung Y.C., Corredig M., Phillips R.D., Chinnan M.C., and McWaters K.H., (2005).

21. Effect of Milling Method on Selected Physical and Functional Properties of Cowpea (Vigna unguiculata) Paste" International Journal of Food Science and Technology 40 (2005): 525-536.

22. Singh B. B., Chambliss O.L., and Sharma B., (1997). Recent advances in cowpea breeding P 30-49 In Singh B.B., et al (e.d) Advances in cowpea research. Co-publication of IITA and JIRCAS, Institute of Tropical Agriculture Ibadan, Nigeria.

23. Tudu D, Mishra HN, Dishri M, Rao KM, Toppo R. Variability and Correlation Studies in Cowpea [Vigna unguiculata L. Walp.] Trends in Biosciences. 2015; 8(1):193-196. 